\title{
Studies on the Biosynthesis of Tetrahymanol in Tetrahymena pyriformis
}

\author{
THE MECHANISM OF INHIBITION BY CHOLESTEROL
}

\author{
By ALAN S. BEEDLE,* KENNETH A. MUNDAY and DAVID C. WILTON \\ Department of Physiology and Biochemistry, The University of Southampton, \\ Medical and Biological Sciences Building, Bassett Crescent East, Southampton SO9 3TU, U.K.
}

(Received 18 January 1974)

Tetrahymanol biosynthesis by the protozoan Tetrahymena pyriformis was progressively inhibited by the inclusion of cholesterol in the growth medium. Studies with labelled precursors of tetrahymanol have established that there are two major sites of inhibition in whole cells. The inhibition at the first site, between acetate and mevalonate, occurred rapidly after addition of cholesterol. The activity of 3-hydroxy-3-methylglutaryl-CoA reductase (EC 1.1.1.34), a predominantly cytosolic enzyme in this organism, was not inhibited in cholesterol-grown cells nor by addition of cholesterol directly to the assay medium. The second major site of inhibition in whole cells is between mevalonate and squalene and this is accompanied by inhibition of the enzyme that converts farnesylpyrophosphate into squalene (squalene synthetase). Squalene cyclase is partially inhibited. The conversion of mevalonate into tetrahymanol in vitro was not inhibited by the addition of cholesterol to the assay medium. Tetrahymanol added to the culture medium is taken up by the cells but does not inhibit endogenous biosynthesis. It is suggested that cholesterol inhibits the later stages of tetrahymanol biosynthesis by causing a change in membrane structure and function which alters the activity of membrane-bound enzymes.

The control of cholesterol biosynthesis has attracted considerable attention in recent years, in particular because of the apparent correlation between high amounts of cholesterol in blood and atherosclerosis.

In the rat the mechanisms for controlling cholesterol biosynthesis are complex, responding to dietary cholesterol intake (Gould et al., 1953), caloric intake (Tomkins \& Chaikoff, 1952) and other dietary and humoral factors (Guder et al., 1968). In an attempt to study a simpler system, we have investigated<smiles>CC1(C)CCCC2(C)C3CCC4(C)C(CCC5C(C)(C)CCCC54C)C3CCC12</smiles>

( I)

\footnotetext{
* Present Address: Department of Biochemistry, University of Liverpool, Liverpool L69 3BX, U.K.
}

the control of biosynthesis of the pentacyclic triterpene tetrahymanol (I) in the protozoan Tetrahymena pyriformis.

This organism does not synthesize sterols (Conner \& Ungar, 1964) but synthesizes tetrahymanol in large amounts, presumably to replace sterols as structural components of membranes (Mallory et al., 1963). Tetrahymanol is formed from the non-oxidative cyclization of squalene (Caspi et al., 1968), which is synthesized from mevalonate. When the organism is grown in the presence of cholesterol, synthesis of tetrahymanol is inhibited (Conner et al., 1968) and the organism takes up and metabolizes the sterol to cholesta-5,7,22-trien-3 $\beta$-ol (Conner et al., 1969). Ergosterol and cholesta-5,7,22-trien-3 $\beta$-ol also inhibit tetrahymanol biosynthesis showing that the process of desaturation of the sterol is not necessary for the inhibitory effect (Mallory \& Conner, 1970).

Previous workers (Conner et al., 1968) have made a radioautographic study of the incorporation of radioactive acetate, mevalonate and squalene into tetrahymanol by whole cells of Tetrahymena and have shown that the major site of inhibition of tetrahymanol biosynthesis is between mevalonate and squalene with a further site at squalene cyclization.

The purpose of the present work was to investigate further the mechanism of cholesterol inhibition of tetrahymanol biosynthesis. 


\section{Materials and Methods}

\section{Materials}

T. pyriformis strain W was obtained from the Culture Collection for Algae and Protozoa, Cambridge, U.K. ATP, CoA, glucose 6-phosphate dehydrogenase (EC 1.1.1.49), glucose 6-phosphate, 3-hydroxy-3methylglutaric acid, mevalonic acid, mevalonic acid lactone, $\mathrm{NAD}^{+}$and $\mathrm{NADP}^{+}$, were obtained from Sigma (London) Chemical Co. Ltd., London S.W.6, U.K. All other chemicals were obtained from BDH Chemicals Ltd., Poole, Dorset, U.K.

3-Hydroxy-3-methyl[3-14 C]glutaric acid was obtained from New England Nuclear Corp., Mannheim, Germany. All other radiochemicals were obtained from The Radiochemical Centre, Amersham, Bucks., U.K.

$\left[{ }^{3} \mathrm{H}\right]$ Squalene was prepared by the incubation of sodium $\left[{ }^{3} \mathrm{H}\right]$ acetate $(100 \mu \mathrm{Ci})$ with a $10000 \mathrm{~g}$ supernatant fraction from rat liver under anaerobic conditions and was purified by t.l.c.

$\left[{ }^{14} \mathrm{C}\right]$ Farnesyl pyrophosphate was prepared by incubation of $\left[2-{ }^{14} \mathrm{C}\right]$ mevalonic acid with a $30-60 \%$ (w/v) $\left(\mathrm{NH}_{4}\right)_{2} \mathrm{SO}_{4}$ fraction from rat liver, and was purified by column chromatography on a DEAEcellulose column by using a stepwise gradient of ammonium formate.

Cholesta-5,7,22-trien-3 $\beta$-ol was prepared by incubation of cholesterol with $T$. pyriformis and was purified by argentation chromatography on plates of silica gel ' $G$ ' containing $10 \%$ (w/v) $\mathrm{AgNO}_{3}$ (Wilton \& Akhtar, 1970).

\section{Growth of cells}

$T$. pyriformis strain $\mathrm{W}$ was grown in a medium containing bacteriological peptone $(2 \%)$, glucose $(0.5 \%)$, yeast extract $(0.1 \%)$ and ethylenediaminetetra-acetic acid ferric monosodium salt $(0.003 \%)$. Cultures were grown in $600 \mathrm{ml}$ of medium in 2 litre Erlenmeyer flasks, maintained at $28^{\circ} \mathrm{C}$ and shaken gently. Stationary phase of growth was reached after $30 \mathrm{~h}$. Cells were harvested by centrifugation at $5000 \mathrm{~g}$ for $10 \mathrm{~min}$. Cell numbers were determined with a Coulter counter.

Cholesterol $(15 \mathrm{mg} / \mathrm{ml})$ was added to cultures dissolved in a minimal amount of ethanol. Control cultures received ethanol only.

\section{Purification of tetrahymanol}

Cells from 8 litres of medium were harvested and refluxed with $100 \mathrm{ml}$ of $10 \%$ methanolic $\mathrm{KOH}(\mathrm{w} / \mathrm{v})$ for $2 \mathrm{~h}$. Water $(100 \mathrm{ml})$ was added and the nonsaponifiable lipids were extracted with three portions of 1 vol. of light petroleum (b.p. $40-60^{\circ} \mathrm{C}$ )-diethyl ether $(1: 1, v / v)$. The ether extracts were combined, dried, evaporated to dryness and the non-saponifiable lipids applied to a preparative thin-layer plate (silica gel ' $\mathrm{G}$ ', $2 \mathrm{~mm}$ thickness) and the plate was developed with light petroleum (b.p. $60-80^{\circ} \mathrm{C}$ )-acetone $(4: 1$, $\mathrm{v} / \mathrm{v})$. The region of the plate at $R_{F} 0.5$ was eluted with diethyl ether and the tetrahymanol recrystallized from ethanol. The tetrahymanol gave one peak on g.l.c. ( $2 \frac{1}{2} \%$ SE30 on Chromosorb G AW-DCMS; column temperature $250^{\circ} \mathrm{C}$; carrier gas $\mathrm{N}_{2}$ at flow rate $50 \mathrm{ml} /$ min) and also gave the correct mass spectrum for tetrahymanol $(m / e$ 428, 413, 410, 395, 207, 191).

$\left[{ }^{14} \mathrm{C}\right]$ Tetrahymanol was prepared in a similar way except that the cells were grown in the presence of $100 \mu \mathrm{Ci}$ of $\left[\mathrm{U}-{ }^{14} \mathrm{C}\right]$ acetate.

\section{Determination of incorporation of radioactive pre- cursors into tetrahymanol}

(i) In vivo. Portions of culture $\left(10 \mathrm{ml}, 10^{6}-10^{7}\right.$ cells) were incubated with sodium [ $\left.{ }^{3} \mathrm{H}\right]$ acetate $(25 \mu \mathrm{Ci})$, potassium $\left[2-{ }^{3} \mathrm{H}\right]$ mevalonate $(10 \mu \mathrm{Ci})$ or $\left[{ }^{3} \mathrm{H}\right]$ squalene $(100 \mu \mathrm{g}, 100000$ d.p.m. in $2 \mathrm{mg}$ of Tween 80$)$ for $30 \mathrm{~min}$ at $28^{\circ} \mathrm{C}$. Under these conditions incorporation into tetrahymanol was linear for at least $45 \mathrm{~min}$. Incubations were terminated by addition of $2 \mathrm{ml}$ of $10 \%$ $(w / v)$ trichloroacetic acid and spinning down the cells, followed by addition of $1 \mathrm{ml}$ of $10 \%$ methanolic $\mathrm{KOH}$ $(\mathrm{w} / \mathrm{v})$.

(ii) In vitro. Portions of culture $\left(200 \mathrm{ml}, 2 \times 10^{7}-\right.$ $2 \times 10^{8}$ cells) were harvested by centrifugation and the pellet suspended in $4 \mathrm{ml}$ of $0.066 \mathrm{M}$-potassium phosphate buffer (pH7.0) containing nicotinamide (30mM), $\mathrm{MgCl}_{2}$ (4mM), 2-mercaptoethanol (5mM) and glycerol $(33 \%, v / v)$.

Cells were disrupted by homogenization in a tightfitting Teflon-glass homogenizer driven by a motor. The homogenate was centrifuged at $500 \mathrm{~g}$ for $10 \mathrm{~min}$ to remove unbroken cells and the supernatant was used for assays.

When incorporation of mevalonate into tetrahymanol was measured incubations contained NADP $(2 \mu \mathrm{mol})$, glucose 6 -phosphate $(4 \mu \mathrm{mol})$, glucose 6phosphate dehydrogenase (1 unit), ATP $(4 \mu \mathrm{mol})$, potassium $\left[2-{ }^{3} \mathrm{H}\right]$ mevalonate $(10 \mu \mathrm{Ci})$ and homogenate $(0.8 \mathrm{ml})$ in a final volume of $1.0 \mathrm{ml}$. Incubations for the assay of the squalene cyclase contained $\left[{ }^{3} \mathrm{H}\right]-$ squalene (100000d.p.m.) in Tween $80(2 \mathrm{mg})$ and homogenate $(0.8 \mathrm{ml})$ in a final volume of $1 \mathrm{ml}$.

In both cases incubation was at $28^{\circ} \mathrm{C}$ for $30 \mathrm{~min}$ (tetrahymanol formation was linear for at least $45 \mathrm{~min}$ ) and incubations were terminated by the addition of $1 \mathrm{ml}$ of $10 \%$ methanolic $\mathrm{KOH}(\mathrm{w} / \mathrm{v})$.

(iii) Isolation of radioactive tetrahymanol. To all incubations was added 5000d.p.m. of $\left[{ }^{14} \mathrm{C}\right]$ tetrahymanol as an internal standard for extraction, and the mixture was saponified and the non-saponifiable lipids extracted as described above. This fraction was applied to a thin-layer $(0.2 \mathrm{~mm})$ silica-gel ' $G$ ' plate and the plate was developed in the solvent described 
above. The gel in the region corresponding to tetrahymanol $\left(R_{F} 0.5\right)$ was scraped into a scintillation vial and the ${ }^{3} \mathrm{H} /{ }^{14} \mathrm{C}$ ratio determined. The incorporation of ${ }^{3} \mathrm{H}$ into tetrahymanol was calculated allowing for recovery of the $\left[{ }^{14} \mathrm{C}\right]$ tetrahymanol standard.

Protein was determined by the biuret assay (Gornall et al., 1949) with bovine serum albumin (BDH Chemicals Ltd.) as the standard.

\section{Assay of hydroxymethylglutaryl-CoA reductase acti- vity}

A cell-free homogenate of Tetrahymena was prepared as described above and was centrifuged at $10000 \mathrm{~g}$ for $20 \mathrm{~min}$. For some experiments microsomal and post-microsomal supernatant fractions were prepared by centrifugation at $100000 \mathrm{~g}$ for $1 \mathrm{~h}$.

Hydroxymethylglutaryl-CoA reductase activity was assayed as previously described (Beedle et al., 1972), except that $0.8 \mathrm{ml}$ of Tetrahymena homogenate was used per incubation and that each $1 \mathrm{ml}$ incubation contained $2 \mu \mathrm{mol}$ of ATP. The assay involves incubations of 3-hydroxy-3-methyl[3-14 C]glutaryl-CoA and isolation of the $\left[3-{ }^{14} \mathrm{C}\right]$ mevalonate formed. Sterols were added to incubations suspended in Tween 80 in vitro.

\section{Assay of squalene synthetase activity}

A $10000 \mathrm{~g}$ supernatant fraction from Tetrahymena was prepared as described above. The assay mixture contained $\left[{ }^{14} \mathrm{C}\right]$ farnesyl pyrophosphate (sp. radioactivity, $1.5 \mu \mathrm{Ci} / \mu \mathrm{mol} ; 10000$ d.p.m.), NADPH $(1 \mu \mathrm{mol})$ and enzyme $(0.8 \mathrm{ml})$. Incubations $(30 \mathrm{~min})$ were terminated by the addition of $0.1 \mathrm{ml}$ of $10 \mathrm{M}$ $\mathrm{KOH}$ and $1 \mathrm{mg}$ of carrier squalene dissolved in light petroleum (b.p. $40-60^{\circ} \mathrm{C}$ ). Non-saponifiable lipids were extracted with three portions of $2 \mathrm{ml}$ of diethyl ether. The pooled ether extracts were dried and evaporated to dryness. The residue was taken up in
$0.1 \mathrm{ml}$ of ether and applied to a silica-gel ' $G$ ' thin-layer plate. The plate was developed with light petroleum (b.p. $40-60^{\circ} \mathrm{C}$ ) and the region of the plate corresponding to authentic squalene $\left(R_{F} 0.4\right)$ was scraped directly into a scintillation vial and assayed for radioactivity.

\section{Results}

The incorporation of radioactive acetate, mevalonate and squalene into tetrahymanol by whole cells was measured. T. pyriformis was grown either in normal medium or in medium containing $15 \mathrm{mg}$ of cholesterol/litre and the ability of the cells to incorporate radioactivity into tetrahymanol from these precursors was investigated. Each experiment was performed in the mid-exponential phase of growth (18h after inoculation) and in the stationary phase (32h after inoculation). The results are shown in Table 1. It is clear that incorporation of all three precursors into tetrahymanol is decreased, irrespective of the phase of growth where synthesis was measured. The major effects of cholesterol occur between acetate and squalene, cyclization of squalene being only slightly affected.

The time-course of the effect of cholesterol was investigated. Since tetrahymanol biosynthesis varies markedly during growth (Beedle et al., 1973), stationary-phase cells were used to keep control incorporations constant. Cholesterol was added to a culture of cells $36 \mathrm{~h}$ after inoculation and incorporation of radioactive precursors into tetrahymanol was measured. The results (Fig. 1) show that the inhibition of acetate incorporation into tetrahymanol occurs fairly rapidly, whereas the inhibition when mevalonic acid or squalene are used as precursors develops rather more slowly. Examination of the incorporation shows that, whereas most of the inhibition occurring in the first hour is due to an effect between acetate and mevalonate, the decrease in acetate incorporation after the first hour can be explained by the inhibition

Table 1. Effect of cholesterol on the incorporation of sodium $\left[{ }^{3} \mathrm{H}\right]$ acetate, $\left[2-{ }^{3} \mathrm{H}\right]$ mevalonic acid and $\left[{ }^{3} \mathrm{H}\right]$ squalene into tetrahymanol by whole cells of $T$. pyriformis

Cells of $T$. pyriformis were grown for the stated length of time in the presence or absence of cholesterol. At these times the ability of the cells to incorporate radioactive precursors into tetrahymanol was measured as described in the Materials and Methods section.

Exponential-phase cells

Total radioactivity in tetrahymanol

\begin{tabular}{|c|c|c|c|c|c|c|}
\hline \multirow[b]{2}{*}{ Precursor } & \multicolumn{2}{|c|}{ (d.p.m.) } & \multirow[b]{2}{*}{$\%$ of control } & \multicolumn{2}{|c|}{ (d.p.m.) } & \multirow[b]{2}{*}{$\%$ of control } \\
\hline & Control & +Cholesterol & & Control & +Cholesterol & \\
\hline $\begin{array}{l}{\left[{ }^{3} \mathrm{H}\right] \text { Acetate }} \\
{\left[{ }^{3} \mathrm{H}\right] \text { Mevalonate }} \\
{\left[{ }^{3} \mathrm{H}\right] \text { Squalene }}\end{array}$ & $\begin{array}{r}197600 \\
93600 \\
19700\end{array}$ & $\begin{array}{r}7900 \\
16900 \\
13800\end{array}$ & $\begin{array}{r}4 \\
18 \\
70\end{array}$ & $\begin{array}{r}23400 \\
21900 \\
8300\end{array}$ & $\begin{array}{l}1900 \\
4800 \\
5400\end{array}$ & $\begin{array}{r}8 \\
22 \\
65\end{array}$ \\
\hline
\end{tabular}

Stationary-phase cells

Vol. 142 
developing after mevalonate and between squalene and tetrahymanol.

The inhibition noted between acetate and mevalonate was analogous to the situation occurring in the liver after feeding cholesterol and could therefore be due to an effect on hydroxymethylglutaryl-CoA reductase. Attempts were therefore made to assay this enzyme in $T$. pyriformis.

Preliminary experiments demonstrated hydroxymethylglutaryl-CoA reductase activity in the $10000 \mathrm{~g}$ supernatant fraction of homogenized cells; however, activity was low and variable. Inclusion of ATP in the assay mixture improved enzyme activity and showed that the enzyme was mainly located in the soluble fraction $(100000 \mathrm{~g}$ supernatant fraction) of the homogenate. This fraction contained $57 \%$ of the total enzyme activity compared with $16 \%$ for the microsomal fraction and $27 \%$ for the mitochondria, nuclei and

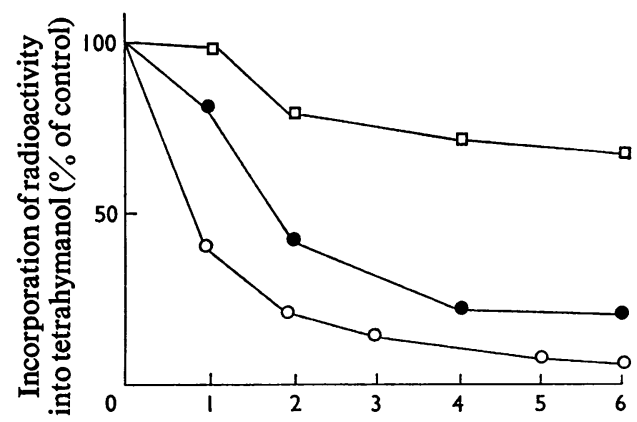

Time after addition of cholesterol (h)

Fig. 1. Time-course of the inhibition by cholesterol of the incorporation of radioactive precursors into tetrahymanol by whole cells of $T$. pyriformis

Precursors are: $\mathrm{O},\left[{ }^{3} \mathrm{H}\right]$ acetate; $\bigcirc,\left[{ }^{3} \mathrm{H}\right]$ mevalonate; $\square,\left[{ }^{3} \mathrm{H}\right]$ squalene. Cholesterol $(15 \mathrm{mg} /$ litre) was added to cells in the stationary phase of growth and the ability of cells to incorporate radioactive precursors into tetrahymanol was measured at times after the addition. For further details see the text. cell debris. The enzyme was assayed as a routine in $10000 \mathrm{~g}$ supernatant fractions in the presence of 2mM-ATP; under these conditions the assay was very reproducible and mevalonate formation was linear for at least $45 \mathrm{~min}$.

Confirmation of the product of the reaction as mevalonate was obtained by further chromatography and by enzymic conversion into squalene. The doubly labelled material isolated from the first chromatography system (containing presumptive $\left[3-{ }^{14} \mathrm{C}\right]-$ mevalonic acid and authentic $\left[2-{ }^{3} \mathrm{H}\right]$ mevalonic acid, ${ }^{3} \mathrm{H} /{ }^{14} \mathrm{C}$ ratio 11.57 ) was subjected to further t.l.c. on silica gel with propan-1-ol- $\mathrm{NH}_{3}$ (sp.gr. 0.880)water $(6: 3: 1$, by vol.) as solvent. A single peak was obtained and the ${ }^{3} \mathrm{H} /{ }^{14} \mathrm{C}$ ratio of the eluted material was essentially unchanged at 9.67. This material was then converted into squalene by a rat liver $10000 \mathrm{~g}$ supernatant preparation under anaerobic conditions. The squalene was extracted, mixed with carrier squalene and purified by the formation of its hexachloride. The ${ }^{3} \mathrm{H} /{ }^{14} \mathrm{C}$ ratio of the squalene was 5.63 , approximately one-half of that of the mevalonic acid. These values correspond to those expected if the ${ }^{14} \mathrm{C}$-labelled material was $3 R-\left[3-{ }^{14} \mathrm{C}\right]$ mevalonic acid arising from the reduction of one isomer of the racemic $\left[3-{ }^{14} \mathrm{C}\right]-$ hydroxymethylglutaryl-CoA by the Tetrahymena hydroxymethylglutaryl-CoA reductase. The decrease in ${ }^{3} \mathrm{H} /{ }^{14} \mathrm{C}$ ratio is caused by the $\left[{ }^{3} \mathrm{H}\right]$ mevalonic acid being racemic and only $50 \%$ of it is a substrate for the rat liver mevalonic acid kinase involved in the conversion of mevalonic acid into squalene.

However, when hydroxymethylglutaryl-CoA reductase was measured in cholesterol-grown cells, no decrease in enzymic activity was noted, even though the incorporation of precursors into tetrahymanol by the whole cells was greatly decreased (Table 2). Clearly hydroxymethylglutaryl-CoA reductase plays no part in the decrease of tetrahymanol biosynthesis in cholesterol-grown cells. As a check on this conclusion the direct effect of sterols on the Tetrahymena hydroxymethylglutaryl-CoA reductase was measured (Table 3). No inhibition was observed, confirming that the enzyme is not sensitive to sterols in vitro.

\section{Table 2. Effect of cholesterol on the activity of hydroxymethylglutaryl-CoA reductase in Tetrahymena}

Cells of $T$. pyriformis were grown in the presence or absence of cholesterol $(15 \mathrm{mg} / \mathrm{litre})$. Then $20 \mathrm{~h}$ after inoculation, incorporation of acetate and mevalonate into tetrahymanol in vivo, and hydroxymethylglutaryl-CoA reductase activity in vitro, were measured as described in the Materials and Methods section.

Tetrahymanol synthesis in vivo (d.p.m. of ${ }^{3} \mathrm{H} / 30 \mathrm{~min}$ per $\mathrm{mg}$ of protein)

\begin{tabular}{lrc}
\cline { 2 - 3 } Cells & {$\left[2-{ }^{3} \mathrm{H}\right]$ Acetate } & {$\left[2-{ }^{3} \mathrm{H}\right]$ Mevalonate } \\
Control & 99790 & 2120 \\
+Cholesterol & 7380 & 771 \\
$\%$ Inhibition & 93 & 64
\end{tabular}

Specific activity of hydroxymethylglutaryl-CoA reductase (nmol of mevalonate formed/h per $\mathrm{mg}$ of protein)

$$
\begin{aligned}
& 9.8 \\
& 9.7
\end{aligned}
$$$$
1
$$ 


\section{Table 3. Effect of sterols on hydroxymethylglutaryl-CoA reductase activity in vitro}

A $10000 \mathrm{~g}$ supernatant fraction was prepared from a $20 \mathrm{~h}$ culture of $T$. pyriformis and hydroxymethylglutaryl-CoA reductase activity was measured as described in the text. Sterols $(50 \mu \mathrm{g})$ dissolved in $2 \mathrm{mg}$ of Tween 80 were added to the incubation.

\section{Addition to incubation}

\section{None}

Tween 80

Cholesterol+Tween 80

Ergosterol+Tween 80

Cholesta-5,7,22-trien-3 $\beta$-ol

+ Tween 80

Squalene+Tween 80

HydroxymethylglutarylCoA reductase activity (nmol of mevalonate/h per $\mathrm{mg}$ of protein)

10.2

10.0

9.9

10.1

10.0

10.2
Table 4. Effect of cholesterol on the conversion of mevalonate and squalene into tetrahymanol by a cell-free system from Tetrahymena

Cells were grown for $20 \mathrm{~h}$ in the presence or absence of cholesterol, harvested and cell-free preparations made, and incorporation into tetrahymanol was measured as described in the Materials and Methods section.

${ }^{3} \mathrm{H}$ radioactivity incorporated into tetrahymanol

(d.p.m./30 min per $\mathrm{mg}$ of protein)

\begin{tabular}{lcc}
\cline { 2 - 3 } Culture & +Mevalonate & +Squalene \\
Control & 10955 & 1679 \\
+Cholesterol & 1752 & 1071 \\
\% Inhibition & 84 & 36
\end{tabular}

Table 5. Effect of sterols on the incorporation of mevalonic acid and squalene into tetrahymanol in vitro by a cell-free preparation from Tetrahymena

Cell-free preparations from $T$. pyriformis were prepared as described in the text and incorporations of mevalonate and squalene into tetrahymanol were measured. Sterols $(50 \mu \mathrm{g})$ dissolved in $2 \mathrm{mg}$ of Tween 80 were added to incubations.

${ }^{3} \mathrm{H}$ radioactivity incorporated into tetrahymanol

(d.p.m./30 min per $\mathrm{mg}$ of protein)

$\begin{array}{lcc}\text { Addition to incubation } & \text { +Mevalonate } & \text { +Squalene } \\ \text { None } & 3976 & 1620 \\ \text { Tween } 80 & 1362 & 1720 \\ \text { Cholesterol+Tween } 80 & 1330 & 1695 \\ \text { Cholesta-5,7,22-trien- } & 1320 & 1650\end{array}$

Table 6. Effect of growth in the presence of cholesterol on the activity of squalene synthetase in Tetrahymena

Cells of T. pyriformis were grown for $20 \mathrm{~h}$ in the presence or absence of cholesterol $(15 \mathrm{mg} /$ litre). At this time the cells were harvested and $10000 \mathrm{~g}$ supernatant fractions prepared from cell-free homogenates as described in the Materials and Methods section. Squalene synthetase activity was assayed as described in the text.

Specific activity of squalene synthetase ( $\mathrm{nmol}$ of squalene formed/h per $\mathrm{mg}$
Cells

\section{Control}

+ Cholesterol

$\%$ Inhibition of protein)

0.39

0.08
The biosynthesis of tetrahymanol in vitro from mevalonate was studied. A $500 \mathrm{~g}$ supernatant fraction from Tetrahymena incorporated radioactivity from mevalonate and squalene into tetrahymanol. The effect of cholesterol on these activities was measured (Table 4). The incorporations from mevalonate and squalene were decreased to $16 \%$ and $64 \%$ of control values respectively, similar inhibitions to those seen in whole cells. Cholesterol added to incubations in vitro was ineffective as an inhibitor (Table 5), although the Tween 80 used to effect solubilization of the sterol was inhibitory at a point between mevalonate and squalene.

It was considered that a possible site for cholesterol to act between mevalonate and squalene was at the level of squalene synthetase, since inhibition of squalene formation from farnesyl pyrophosphate would still allow biosynthesis of other isoprenoid compounds (for example ubiquinone) to continue. Consequently, squalene synthetase activity was assayed in cell-free homogenates of both normal and cholesterolgrown cells. The results in Table 6 show that the specific activity of the enzyme in cells grown in the presence of cholesterol is decreased to about $20 \%$ of that of the enzyme in control cells, corresponding closely to the inhibition of tetrahymanol formation from mevalonate both in whole cells and in vitro.

However, some effect of incorporation of acetate was observed before incorporation of mevalonate was seriously affected. Since no change in hydroxymethylglutaryl-CoA reductase activity was seen, it was thought that this effect, observed in whole cells, could be due to an isotope-dilution effect, where an increase in the acetate pool for tetrahymanol biosynthesis would lead to an apparent decrease in the incorporation of label into tetrahymanol. To test this hypothesis the incorporation of ${ }^{3} \mathrm{H}_{2} \mathrm{O}$ into tetrahymanol was measured in parallel with the incorporation of $\left[{ }^{14} \mathrm{C}\right]-$ acetate into cells grown in the presence and absence of cholesterol. ${ }^{3} \mathrm{H}$ is incorporated into tetrahymanol wherever protons are used to form $\mathbf{C}-\mathbf{H}$ bonds during

Vol. 142 


\section{Table 7. Effect of cholesterol on the incorporation of ${ }^{3} \mathrm{H}_{2} \mathrm{O}$ and $\left[\mathrm{U}-{ }^{14} \mathrm{C}\right]$ acetate into tetrahymanol in vivo}

A culture of stationary-phase cells ( $32 \mathrm{~h}$ after inoculation) was divided into two and cholesterol $(15 \mathrm{mg} / \mathrm{litre})$ was added to one part. After $1 \mathrm{~h}$ further incubation, a $10 \mathrm{ml}$ portion of cells was taken from each culture and incubated with ${ }^{3} \mathrm{H}_{2} \mathrm{O}$ $(300 \mathrm{mCi})$ and $\left[\mathrm{U}-{ }^{14} \mathrm{C}\right]$ acetate $(5 \mu \mathrm{Ci})$. The incubations were terminated after $30 \mathrm{~min}$ and freeze-dried to remove ${ }^{3} \mathrm{H}_{2} \mathrm{O}$. Tetrahymanol was isolated as described in the text, except that no $\left[{ }^{14} \mathrm{C}\right]$ tetrahymanol standard was added.

\begin{tabular}{|c|c|c|c|}
\hline Cells & $\begin{array}{c}{ }^{3} \mathrm{H} \text { radioactivity in tetrahymanol } \\
\text { (d.p.m.) }\end{array}$ & $\begin{array}{c}{ }^{14} \mathrm{C} \text { radioactivity in tetrahymanol } \\
\text { (d.p.m.) }\end{array}$ & ${ }^{3} \mathrm{H} /{ }^{14} \mathrm{C}$ ratio \\
\hline $\begin{array}{l}\text { Control } \\
+ \text { Cholesterol }\end{array}$ & $\begin{array}{l}3522 \\
1354\end{array}$ & $\begin{array}{l}7855 \\
2490\end{array}$ & $\begin{array}{l}0.448 \\
0.543\end{array}$ \\
\hline$\%$ Inhibition & 61.6 & 68.4 & \\
\hline
\end{tabular}

Table 8. Subcellular distribution of exogenous and endogenous tetrahymanol

A portion $(10 \mathrm{ml})$ of a $20 \mathrm{~h}$ culture was incubated with $\left[{ }^{14} \mathrm{C}\right]$ tetrahymanol $\left(500 \mu \mathrm{g} ; 100000\right.$ d.p.m.) and $\left[{ }^{3} \mathrm{H}\right]$ acetate $(25 \mu \mathrm{Ci})$. After $6 \mathrm{~h}$ incubation the cells were harvested, washed with $50 \mathrm{~mm}$-potassium phosphate buffer (pH7.0), resuspended in the buffer and disrupted by homogenization. Cell fractions were isolated by differential centrifugation and tetrahymanol isolated from each fraction as described in the Materials and Methods section.

$\begin{array}{lccc}\text { Fraction } & \begin{array}{c}\left.{ }^{3} \mathrm{H}\right] \text { Tetrahymanol } \\ \text { (d.p.m.) }\end{array} & \begin{array}{c}\left.{ }^{14} \mathrm{C}\right] \text { Tetrahymanol } \\ \text { (d.p.m.) }\end{array} & { }^{3} \mathrm{H} /{ }^{14} \mathrm{C} \text { ratio } \\ 1000 \mathrm{~g} \text { pellet (membranes, cilia, nuclei) } & 19450 & 19989 & 0.973 \\ 10000 \mathrm{~g} \text { pellet (mitochondria) } & 2420 & 2089 & 1.159 \\ 10000 \mathrm{~g} \text { supernatant (microsomal fractions, supernatant) } & 1619 & 1751 & 0.925\end{array}$

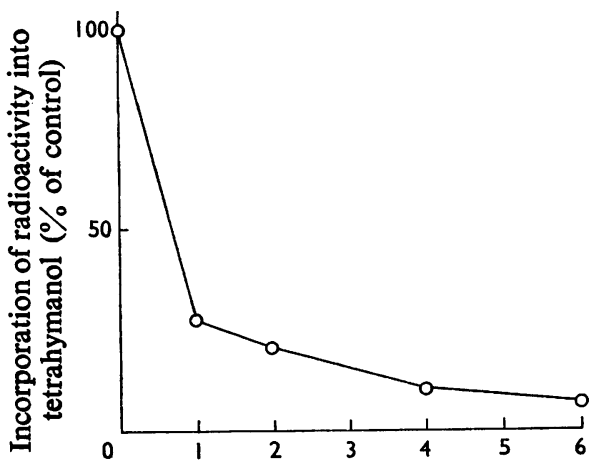

Time after addition of cycloheximide (h)

Fig. 2. Time-course of inhibition of tetrahymanol biosynthesis with cycloheximide as inhibitor

Cycloheximide $(5 \mu \mathrm{g} / \mathrm{ml})$ was added to a culture of $T$. pyriformis $32 \mathrm{~h}$ after inoculation. The ability of the cells to incorporate $\left[{ }^{3} \mathrm{H}\right]$ acetate into tetrahymanol was measured at the times indicated.

biosynthesis, hence the ${ }^{3} \mathrm{H}$ incorporation will be proportional to the actual flux of precursors through the pathway. Any variation of ${ }^{3} \mathrm{H} /{ }^{14} \mathrm{C}$ ratio in the tetrahymanol from the two types of cells would indicate an isotope-dilution effect. The results in Table 7 show that there is a similar inhibition from ${ }^{3} \mathrm{H}_{2} \mathrm{O}$ and
[U- $\left.{ }^{14} \mathrm{C}\right]$ acetate and therefore the decrease of incorporation of label from $\left[{ }^{3} \mathrm{H}\right]$ acetate into tetrahymanol on addition of cholesterol is a genuine effect and is not due to isotope dilution.

A decrease in the activity of a biosynthetic pathway can be explained either by a direct inhibition of the activity of the enzymes involved or by a decrease in the amount of enzyme present. The latter explanation is suggested by the results obtained, where added sterols had no effect on the conversion of mevalonate into tetrahymanol in vitro. To see the effect of inhibitors of protein synthesis on tetrahymanol biosynthesis a time-course experiment similar to that described above was carried out, except that cycloheximide was added to the culture instead of cholesterol. $\left[{ }^{3} \mathrm{H}\right]$ Acetate was used as precursor and the results are shown in Fig. 2. Clearly the time-course is similar to that seen when cholesterol was added, suggesting that inhibition of protein synthesis, or some closely related phenomenon, plays a large part in the decrease of tetrahymanol biosynthesis by cholesterol.

At the start of this work, it was assumed that cholesterol was acting as a tetrahymanol analogue and the cholesterol inhibition was the reflexion of a normal feedback control system. However it was subsequently observed (Mallory \& Connor, 1970; A. S. Beedle, K. A. Munday \& D. C. Wilton, unpublished work) that the addition of tetrahymanol to the culture did not inhibit its own synthesis. 
Table 9. Subcellular distribution of cholesterol and tetrahymanol

A portion $(10 \mathrm{ml})$ of a $20 \mathrm{~h}$ culture was incubated with $\left[{ }^{14} \mathrm{C}\right]$ tetrahymanol $(500 \mu \mathrm{g} ; 100000$ d.p.m. $)$ and $\left[19-{ }^{3} \mathrm{H}\right]$ cholesterol $(500 \mu \mathrm{g} ; 150000$ d.p.m.). After $6 \mathrm{~h}$ incubation, the culture was harvested, subcellular fractions were prepared and radioactivity in the non-saponifiable lipid fraction of each fraction was measured.

\begin{tabular}{lccc}
\multicolumn{1}{c}{$\begin{array}{c}\text { Fraction } \\
\text { Original mixture }\end{array}$} & ${ }^{3} \mathrm{H} /{ }^{14} \mathrm{C}$ ratio & $\begin{array}{c}{\left[{ }^{3} \mathrm{H}\right] \text { Cholesterol }} \\
\text { (d.p.m.) }\end{array}$ & $\begin{array}{c}{\left[{ }^{14} \mathrm{C}\right] \text { Tetrahymanol }} \\
\text { (d.p.m.) }\end{array}$ \\
$1000 \mathrm{~g}$ pellet & 1.268 & & \\
$10000 \mathrm{~g}$ pellet & 1.183 & 6920 & 5850 \\
$10000 \mathrm{~g}$ supernatant & 1.259 & 5100 & 4050 \\
& 1.676 & 650 & 390
\end{tabular}

We considered the possibility that exogenous tetrahymanol might not be able to enter the cells and hence could not reach the site of inhibition. To test this hypothesis, the subcellular distribution of endogenous (generated from $\left.\left[{ }^{3} \mathrm{H}\right] a c e t a t e\right)$ and exogenous $\left({ }^{14} \mathrm{C}\right.$ labelled) tetrahymanol was measured. Cells were incubated with the two labelled substrates and subcellular components were isolated by differential centrifugation of homogenates. Tetrahymanol was isolated from each fraction. The results in Table 8 show that the distribution of ${ }^{3} \mathrm{H}$ and ${ }^{14} \mathrm{C}$ radioactivity throughout the cell is approximately constant (constant ${ }^{3} \mathrm{H} /{ }^{14} \mathrm{C}$ ratio), suggesting that exogenous and endogenous tetrahymanol are in equilibrium throughout the cell.

In a similar experiment (Table 9) incubation was with $\left[{ }^{14} \mathrm{C}\right]$ tetrahymanol and $\left[19-{ }^{3} \mathrm{H}\right]$ cholesterol, and again it seems that exogenous tetrahymanol and cholesterol are in equilibrium throughout the cell.

From these experiments it appears that exogenous tetrahymanol does penetrate the cell and equilibrate with endogenous tetrahymanol, and hence the failure of exogenous tetrahymanol to inhibit tetrahymanol biosynthesis must be considered a genuine phenomenon.

\section{Discussion}

The biosynthesis of tetrahymanol by $T$. pyriformis is progressively inhibited with time when cholesterol is added to the culture medium. There appear to be two stages to this inhibition. An initial rapid inhibition between acetate and mevalonate occurs within the first hour of growth in the presence of cholesterol and this is followed by a more progressive inhibition between mevalonate and tetrahymanol.

The most obvious site for the initial inhibition between acetate and mevalonate is the enzyme 3hydroxy-3-methylglutaryl-CoA reductase. However, when the activity of this enzyme was determined in cells grown in the presence of cholesterol it was identical with that found in normal cells, and the addition of cholesterol to the enzyme in vitro was also without effect. The precise nature of the inhibition remains obscure and will require the assay of other premevalonate enzymes. It is possible though that this inhibition may reflect a more general metabolic phenomenon since a similar inhibition of acetate incorporation into lipids was noted in cholesterolgrown cells. Tetrahymanol biosynthesis must eventually be completely inhibited because the total tetrahymanol content of a culture grown through nine generations in the presence of cholesterol is essentially the same as would have been provided by the initial innoculum. Therefore it seems unlikely that the acetate inhibition would contribute significantly to this long-term inhibition since otherwise lipid synthesis would also have to cease.

It is probable that the inhibition between mevalonate and tetrahymanol is the more significant longterm effect for bringing about a total cessation of tetrahymanol biosynthesis (see also Conner et al., 1968). Assays of individual enzymes in vitro suggest that the primary site of inhibition is at the level of squalene synthetase with a smaller inhibition of squalene cyclase. The inhibition is not mediated by the direct action of cholesterol in vitro, but appears to be correlated with actual protein synthesis within the cell. The inhibition is not a reflexion of a natural feedback system because addition of tetrahymanol does not inhibit its own biosynthesis. It seems unlikely that this organism should have evolved a specific mechanism for inhibiting tetrahymanol biosynthesis whenever it happened to be growing in the presence of sterols such as cholesterol or ergosterol. If this were the case a much more effective point of inhibition would be early in the pathway rather than at the level of squalene synthetase since the major requirement for this pathway must be for tetrahymanol biosynthesis. Other mevalonate-derived compounds such as the ubiquinones would require only very low enzyme activity.

An explanation consistent with the observations reported in the present paper is that the cholesterol effect does not reflect a natural feedback system, but that the sterol causes structural changes in the membranes. It is known that the inclusion of ergosterol in the membranes results in a change in their fatty acid 
(a) Sequence of active sites

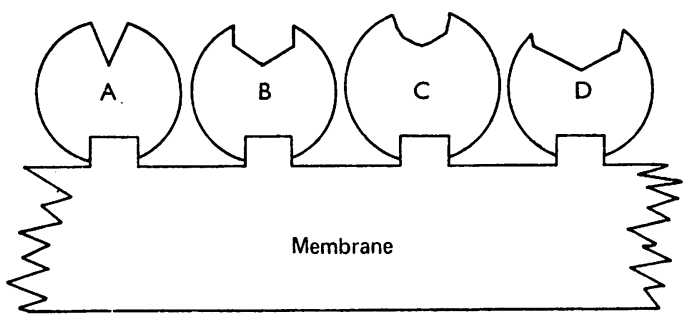

Protein and lipid including tetrahymanol

(b) Active sites masked

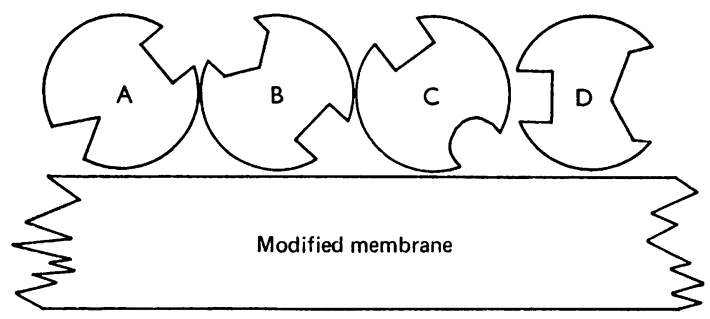

Protein and lipid including cholesterol

Scheme 1. Possible model for conformational change caused by incorporation of cholesterol into Tetrahymena membranes

A, B, C and D are enzymes for the biosynthesis of tetrahymanol and are normally bound to a membrane in an ordered sequence. $(a)$, normal cell; $(b)$, cell grown with cholesterol.

composition to accommodate the larger ergosterol molecule (Conner et al., 1971; Ferguson et al., 1971). Such structural alterations could disturb the configuration of enzymes in newly formed membranes such that their efficiency is decreased. Hence the inhibition of tetrahymanol biosynthesis by cholesterol could manifest itself where the reorientation of a particular membrane-bound enzyme altered its activity whereas added tetrahymanol would not alter membrane structure. The onset of inhibition by adding cholesterol would parallel closely the effect of adding protein-synthesis inhibitors, since only newly synthesized membranes containing cholesterol would have enzymes so affected. A diagrammatic representation of enzyme misalignment is shown in Scheme 1.

\section{References}

Beedle, A. S., Munday, K. A. \& Wilton, D. C. (1972) Eur. J. Biochem. 28, 151-155

Beedle, A. S., Munday, K. A. \& Wilton, D. C. (1973) Biochem. Soc. Trans. 1, 1319-1321

Caspi, E., Greig, J. B. \& Zander, J. M. (1968) Biochem. J. 109, 931-932

Conner, R. L. \& Ungar, F. (1964) Exp. Cell Res. 36, 134-144

Conner, R. L., Landrey, J. R., Burns, C. H. \& Mallory, F. B. (1968) J. Protozool. 15, 600-605

Conner, R. L., Mallory, F. B., Landrey, J. R. \& Iyengar, C. W. L. (1969) J. Biol. Chem. 224, 2325-2333

Conner, R. L., Mallory, F. B., Landrey, J. R., Ferguson, K. A., Kaneshiro, E. S. \& Ray, E. (1971) Biochem. Biophys. Res. Commun. 44, 995-1000

Ferguson, K. A., Conner, R. L. \& Mallory, F. B. (1971) Arch. Biochem. Biophys. 144, 448-450

Gornall, A. G., Bardawill, C. S. \& David, M. M. (1949) J. Biol. Chem. 177, 751-766

Gould, R. G., Taylor, C. B., Hagerman, J. S., Warner, I. \& Campbell, D. J. (1953) J. Biol. Chem. 201, 519-528

Guder, W., Nolte, I. \& Wieland, O. (1968) Eur.J. Biochem. 4, 273-278

Mallory, F. B. \& Conner, R. L. (1970) Lipids 6, 149-153

Mallory, F. B., Gordon, J. T. \& Conner, R. L. (1963) J. Amer. Chem. Soc. 85, 1326-1363

Tomkins, G. M. \& Chaikoff, I. L. (1952) J. Biol. Chem. 196, 569-573

Wilton, D. C. \& Akhtar, M. (1970) Biochem. J. 116, 337 339 